\title{
The Effects of Job Embeddedness on Organizational Cynicism and Employee Performance: A Study on Sadat City University
}

\author{
Wageeh Nafei ${ }^{1}$ \\ ${ }^{1}$ University of Sadat City, Menoufia, Egypt \\ Correspondence: Wageeh Nafei, University of Sadat City, Menoufia, Egypt. E-mail: dr.wageeh1965@yahoo.com
}

Received: June 4, 2014

Accepted: December 9, 2014

Online Published: December 17, 2014

doi:10.5430/ijba.v6n1p8

URL: http://dx.doi.org/10.5430/ijba.v6n1p8

\begin{abstract}
Purpose: Using a new construct, Job Embeddedness (JE), from the business management literature, this study examines the effects of JE on Organizational Cynicism (OC) and Employee Performance (EP) at Sadat City University.

Research Design/Methodology: Using Mitchell et al., 2001 of JE, the study develops a number of hypotheses and tests them. Out of the 692 questionnaires that were distributed to employees at Sadat City University in Egypt, 400 usable questionnaires were returned, a response rate of $58 \%$.

Findings: The results showed that JE is related to the OC and EP. In other words, fit, links and sacrifice significantly correlated with OC and EP. This research outlined a strong relationship between JE, OC and EP. The study findings suggest that improving JE will have a positive impact EP.

Practical implications: The study suggests that the University of Sadat City in Egypt can improve EP by influencing its JE, specifically, by developing fit, links and sacrifice. The study provided that it is necessary to pay more attention to the dimensions of JE as a key source for organizations to enhance the competitive advantage which is of prime significance for $\mathrm{OC}$ and $\mathrm{EP}$.

Originality/value: JE is valuable for evaluating employee retention in Sadat City University. The study observes that there is a critical shortage of JE and that a greater understanding of the factors that influence the EP, including fit, links and sacrifice, is of great importance. Therefore, this study is to examine the relationship between JE, OC and EP among employees at Sadat City University.
\end{abstract}

Keywords: job embeddedness, organizational cynicism, employee performance

\section{Introduction}

Job Embeddedness (JE) theory represents one of these new perspectives (Holtom et al., 2008), focusing on factors that encourage an employee to remain with an organization. Several studies reveal that JE predicts incremental variation in turnover after controlling for traditional turnover predictors, such as job satisfaction and quit intentions (Crossley et al., 2007; Mallol et al., 2007).

JE theory is a broad constellation of psychological, social, and financial influences on employee retention (Yao et al., 2004). These influences are present on the job, as well as outside the employee's immediate work environment, and are often likened to strands in a "web" or "net" in which a person can become "stuck" (Mitchell et al., 2001).

$\mathrm{JE}$ is comprised of (1) the links one has to others, (2) the fit with the organization and community, and (3) how much one would have to sacrifice to change jobs (Lee et al., 2004; Holtom \& Inderrieden, 2006).

JE research has extended to other outcomes such as performance and social capital (Sekiguchi et al., 2008). It is a retention or anti-withdrawal construct. JE was composed of factors such as the overall fit employees have with the organization, it would yield positive outcomes. JE should lead to the development of human and social capital for two reasons. First, for highly embedded individuals, there is good fit of the employees' existing knowledge, skills and abilities with the requirements of the organization that provides opportunities for the natural extension and development of additional and complimentary skills. Second, the highly embedded employees have many links with more important individuals which provide opportunities to develop additional social capital. In fact, there is a positive relationship between JE and social capital but found declines in social capital development over time ( $\mathrm{Ng} \&$ Feldman, 2010). 
JE represents rich social ties, job fit, and personal investment in a job or organization and the community that in turn create opportunities for the employee to extend and develop new skills and social ties with others (Holtom et al., 2006).

JE have numerous features; these are (a) work or organizational options by way of choosing your clients, (b) empowerment, or mentoring activities, and (c) non-worker social embeddedness (Van Emmerik \& Sanders, 2004) which includes direct links to family, non-work activities, off-the-job interests, and job and embeddedness in the organization (Mitchell et al., 2001).

\section{Literature Review}

\subsection{Job Embeddedness}

The term "embeddedness" has been used in the sociological literature to explain the process by which social relations influence and constrain economic action (Granovetter, 1985; Uzzi, 1996, 1997).

Embeddedness is the idea that individuals can become enmeshed in their surrounding and situation to such an extent that they have a difficult time separating from it (Ng \& Feldman, 2009).

It is distinct in that it not only represents factors that influence attitudes and intentions toward behaviors on-the-job, but community and social aspects also come into play that influence job behaviors (Crossley, et al., 2007).

Embeddedness suggests that there are numerous strands that connect an employee and his or her family in a social, psychological, and financial web that includes work and non-work friends, groups, then on-work, and the physical environment in which he or she lives. More recently, a new construct was introduced to help define why people stay on their jobs, called JE (Mitchell, et al., 2001).

$\mathrm{JE}$ is a new concept for how well a person was socially enmeshed within their organization (Granovetter, 1985). It is relatively a new concept and is under-researched in the hospitality management and marketing literature (Karatepe \& Ngeche, 2011).

JE reflects employees' decisions to participate broadly and directly, and it moves scholarly attention beyond dissatisfaction-induced leaving. More aptly, JE is a retention (or "antiwithdrawal") construct (Dong-Hwan \& Jung-Min, 2012).

It encompasses the total forces on an individual causing the person to remain at his/her current job. JE has been empirically demonstrated to impact work-related behaviors such as turnover, performance, absenteeism and citizenship behaviors (Ng \& Feldman, 2009).

JE has been conceptualized to consist of two dimensions: on-the-job (organizational) embeddedness and off-the-job (community) embeddedness. On-the-JE refers to the degree to which individuals are immersed in their organizations, while off-the-JE represents the degree to which individuals are immersed in their communities. On-the-JE better predicts employee job performance than does the off-the-JE. Furthermore, the On-the-JE better predicts employee retention than does the off-the-JE. Each embeddedness dimension is composed of three facets: fit, links, and sacrifice (Allen, 2006).

It is a new construct developed to capture a more comprehensive view of the employee-employer relationship than is typically reflected by attitudinal measures such as satisfaction or commitment. JE is constellation of influences which enmesh or embed people within organizations. Consequently, the embedded employee either finds it more difficult to leave or does not want to leave the organization to which they have become a part (Mitchell et al., 2001).

$\mathrm{JE}$ is the combined material, financial, and psychological factors that keep a person from leaving his or her job. Theoretically, workplace friendships could increase JE by creating social links, perceptions of fit and greater sacrifice of having to leave work friends if a new job opportunity was present. JE is conceptualized as influencing the decision to remain through the level of links a person has to other people or activities, the extent that the person's job and community are congruent with the other aspects of their life, and the sacrifices a person would make in the process of leaving their employment. It is an assemblage of psychological, social, and financial influences that determine employee retention (Mitchell et al., 2001).

$\mathrm{JE}$ is an employee retention theory and evolved from the unfolding model voluntary employee turnover (Lee et al., 1996).

If JE is indeed a broad-based retention (antiwithdrawal) construct and if it captures a sizable portion of the "decision to participate," both on- and off-the-JE should predict not only employee turnover, but also other withdrawal behaviors, such as decreasing organizational citizenship behavior, decreasing performance, and increasing absence. 
Further, the explained variance in these withdrawal behaviors should exceed that explained by job satisfaction and organizational commitment (Hulin, 1998).

Because on-the-JE correlates to job satisfaction, organizational commitment, and turnover, it should predict subsequent absences as well (Griffeth et al., 2000).

However, the effect of on-the-JE on absences and turnover may be reduced to zero when researchers control for satisfaction and commitment. Further, off-the-JE predicts absences and turnover, and it may do so even when satisfaction and commitment are controlled for. That is, leaving a job may have significant effects on an individual's off-the-job life, especially if he or she has to relocate to find new employment. More specifically, people who are embedded in their communities should want to keep their jobs (Hulin, 1998).

High levels of JE indicate that a person feels a sense of compatibility between his or her personal career needs, goals and values and those of the job and organization; experiences positive formal and informal connections between himself or herself and the team or organization; and perceives the costs of leaving the job as being too high (Mitchell et al. 2001).

\subsection{The Dimensions of Job Embeddness}

The three component dimensions of JE include links, fit and sacrifice (Mitchell et al., 2001). JE explains why employees remain in an organization based on a number of influences rather than solely on positive job attitudes. JE suggests that people remain in organizations based on three criteria which are influenced by elements both on the job and in the community: (1) the extent to which they are linked to other people and activities, (2) the extent to which they feel they fit in their organizations and communities, and (3) what they would have to sacrifice if they left (Mitchell et al., 2001).

The links aspect of embeddedness suggests that employees have formal and informal connections with other entities on the job and, as the number of those links increases, embeddedness is higher. Fit refers to the match between an employee's goals and values and those of the organization; higher fit indicates higher embeddedness. Finally, sacrifice concerns the perceived costs of leaving the organization, both financial and social. The higher the perceived costs, the greater the embeddedness (Holtom et al., 2006).

The greater the extent of fit, the higher number of links and level of sacrifice, the more embedded an individual will be in his or her job (Sekiguchi et al., 2008).

\subsubsection{Fit}

Organizational fit is the degree of similarity or compatibility between the individual and organizational culture, overlap between the individual abilities and organizational demands, and match between individual interests and organizational rewards. Community fit is the degree of match, similarity, or compatibility between the individual and his or her community (Ng \& Feldman, 2009).

Fit is the individual's perceived compatibility with the organization and with the community. The employee's personal values and career goals need to be in line with the overall organizational culture, allowing the employee to feel connected to the organization. Additionally, the individual needs to feel a fit between his or her family and the local community (Felbs, et al., 2009).

A person who perceives person-organization fit would find it difficult to leave an organization. People take jobs for other fit reasons, including proximity to extended family, climate considerations, and culture (Valle, 2006).

JE was significantly enhanced by off-the-job, or community fit. Perceptions of fit within an organization and in the community would likely lead to decreased turnover intentions (Lee et al., 2004).

Fit is an employee's perceived compatibility or comfort with an organization and with his or her environment. Ensuring that individuals fit well within the organization's environment is one way for managers to reduce early turnover (Snow, 2002).

The degree to which people's lives align with their jobs and communities is called fit (Mitchell et. al., 2001). An employee's personal values, career goals and plans for the future must "fit" with the larger corporate culture and the demands of his or her immediate job. In addition, a person will consider how well he or she fits the community and surrounding environment (Mitchell et. al., 2001).

Fit has often been described as an employee's perceived compatibility with his or her organization. This construct has been further described as a composite of person-organization fit (Chatman, 1989) and person-job fit (Careless, 2005). Studies have shown that poor person-organization fit leads to turnover (Villanova et al., 1994). 


\subsubsection{Links}

Links mean that each individual is linked to other people, teams, and organizations officially or unofficially (Dong-Hwan \& Jung-Min, 2012).

Links refer to the formal or informal connections of individuals with other people, projects, locations, activities, and groups in their organizations and communities ( $\mathrm{Ng} \&$ Feldman, 2009).

The more connected an individual and/or his or her family is with the organization and the community, the more difficult leaving is and the more embedded the person is (Felbs, et al., 2009).

One can become embedded in an organizational web of connections, much as one can become heavily involved in family and social links outside of work (Valle, 2006).

Links are characterized as formal or informal connections between a person, and institutions or other people (Lee et al., 2004).

Links are the degree to which people have connections to other people and activities. JE suggests that a number of strands connect an employee and his or her family in a social, psychological, and financial web that includes work and non-work friends, groups, the community, and the physical environment in which he or she lives (Mitchell et. al., 2001).

\subsubsection{Sacrifice}

Sacrifice refers to the ease with which the links can be broken upon quitting work or moving to another home or community. Specifically, it is grounded in the perceived cost of material and psychological benefits that would be given up upon leaving the job or community ( $\mathrm{Ng} \&$ Feldman, 2009).

Sacrifice refers to the perceived costs associated with leaving. These costs may be physical or psychological. Leaving may mean giving up the advantages associated with tenure in the organization (pay, corner office), as well as the personal losses such as close friendships with coworkers or benefits unique to the organization. Community sacrifices are applicable only if the person will move to a new location (Felbs, et al., 2009).

Sacrifice is the individual's perceived cost (in psychological and financial terms) of job change. The psychological costs may include those associated with leaving friends or family and job conditions which one desires. Financial costs may include relocation of related expenses (Fields et al., 2005).

Sacrifice means the opportunity cost of turnover, which is the perceived cost of physical or psychological convenience sacrificed when leaving a current job. Recent research suggests that job attitude has relatively little influence on the stay or turnover of the employees. Other factors than job satisfaction, organizational commitment, and job alternatives stand out to understand turnover (Park \& Lee, 2004).

Sacrifice to the organization was defined as the perceived cost of physical or psychological convenience sacrificed when leaving a current job (Mitchell et al., 2001).

Sacrifice captures the perceived cost of material or psychological benefits that may be forfeited by leaving one's job. For example, leaving an organization likely promises personal losses (Taunton, 1997; Shaw, et al., 1998). Though comparable salary and benefits may be easily found in an environment of low unemployment, the switching costs are real and relevant (Gupta \& Jenkins, 1980).

\subsection{Organizational Cynicism}

There are different types of cynicism such as social cynicism, employee cynicism, civil servant cynicism, work cynicism and Organizational Cynicism (OC) (Dean et al., 1998).

General cynicism is an inborn and determined personality trait which reflects generally negative perceptions about human behavior. Cynicism is a defensive response, because it can shield employees against feeling strong emotions and prepare them for the next "inevitable failure" (Abraham, 2000).

Cynicism is an individual's having negative feelings, such as anger, disappointment, hopelessness, about many problems both for the staff and organizations (Özler Ergun et al., 2010).

Cynicism is an evaluative judgment that stems from an individual's employment experiences. Furthermore, irrespective of the accuracy or validity of the individual's perceptions on which the employee cynicism construct is based, it is real in its consequences (Bruch, \& Vogel, 2006).

Cynicism can be expressed both overtly, such as through direct statements questioning the integrity of the organization, and covertly through the use of sarcastic humor and nonverbal behaviors, such as "knowing 1 looks," "rolling eyes," and "smirks" (Dean et al., 1998). 
Cynicism is a negative and is therefore a sensitive topic to managers and organizations. Because of this sensitivity, negative attitudes as well as the organizational practices that foster them have been relatively neglected in management research (Andersson (1996).

Cynics may feel embarrassment, hatred and even dishonor when they think about their organizations. Business ethics is a system, principles, codes or values, which provide guidelines for morally right behavior and honesty in specific situations (Lewis 1985).

OC is an individual negative feelings, such as disturbance, dissatisfaction and hopelessness about the staff and organization (Ozler et al., 2011).

It is an attitude that involves unfriendliness from the organization due to a confidence that the organization lacks honesty and will always attempt to fool its employees (Nair \&Kamalanabhan, 2010).

OC concept is based and not depending on a single theory, when it is considered conceptually, are expectancy theory, attribution theory, attitude theory, social exchange theory, emotional events theory and social motivation theory. OC concept is the negative attitudes of an individual in connection with his/her organization (Kalağan, 2009).

It arises when employees believe that their organization is deficient in honesty. This may especially result from the perception of which is expectations related to morality, justice and honesty are despoiled. OC takes place when employees think that their organization is lacking integrity. OC is not simply the feelings that 'negative' people bring into the organization, but that these attitudes are shaped by experiences in the work context" (Johnson \& O’Leary-Kelly, 2003).

$\mathrm{OC}$ is an attitude, characterized by frustration and negatively beliefs, resulting primarily from unmet expectations, which is capable of being directed towards an organization in general and/or more specific facets of the organizational environment (Brockway et al., 2002).

It refers to the lack, among workers, of the feelings of righteousness, confidence, fairness and sincerity towards the organization where they work (Abraham, 2000).

OC is a learned response rather than a personality-based predisposition (Wanous et al., 2000). It is a negative attitude towards the organization where one works, which has cognitive, affective and behavioral dimensions (Dean, et al., 1998).

OC was found to have negative relationships with organizational commitment, organizational citizenship behavior, and job satisfaction (Andersson \& Bateman, 1997).

It is a negative attitude that develops as a result of perceived malfeasance of the agent or entity. Such a negative attitude can be directed at the organization as a whole and/or the individuals in the organization (Reicher et al., 1997).

OC is a general and specific attitude characterized with anger, hopelessness, disappointment and a tendency to distrust individuals, groups, ideologies, social abilities or institutions (Andersson, 1996).

It exists as a resistance against improvement of the organization and severely damaging the organization (Zapf et.al., 1996; Davenport et.al., 2003; Pitre, 2004; Arabac1, 2010).

\subsection{Organizational Cynicism Dimensions}

OC is a negative attitude with three dimensions towards the organization where one works. These dimensions are (1) a belief that the organization lacks integrity; (2) negative affect toward the organization; and (3) tendencies to disparaging and critical behaviors toward the organization (Kutanis \& Çetinel, 2009). OC is a complex process which culminates in a belief that the organization is not fair (Dean et al., 1998).

\subsubsection{Cognitive Dimension}

The first dimension is the belief in the organization's lack of honesty. The cognitive (belief) dimension of OC consists of the belief that the organization's practices are deficient in justice, honesty and sincerity (Dean et al., 1998). Cognitive dimension refers to employees' disbelief in their organizations. (Urbany, 2005). Due to these beliefs, they think that the organizational practices betray them (Dean et al., 1998).

\subsubsection{Emotional Dimension}

Emotional /sentimental reactions to the organization are the second dimension of OC. The sensitive/emotional dimension of OC consists of strong emotional reactions towards the organization (Dean et al., 1998).

Emotional dimension consists of emotional reactions such as anxiety, shame, anger, disappointment (O'Leary, 2003) or rage/pessimism (Brandes, 1999). OCs of emotional dimension contains some powerful emotional reactions like disrespect, anger, boredom and shame (Abraham, 2000). 


\subsubsection{Behavioral Dimension}

The last dimension refers to negative tendencies and mainly humiliating attitudes. Behavioral dimension, the last dimension of OC, consists of negative and frequently critical attitudes. The most prominent of behavioral tendencies is strong critical expressions towards the organization (Dean et al., 1998).

Behavioral dimension covers employees' fierce criticisms of the organization such as condescension, denigration and belittlement (Turner \& Valentine, 2001). In this dimension, the employee may get alienated from or sever her ties with the organization (O'Brien et al., 2004).

\subsection{Job Performance}

Performance is a reflection of the organization's ability to achieve its goals (Miller \& Broamiley, 1990). It is a combination of resources, capabilities of the organization that are being used efficiently and effectively in order to achieve its objectives (Collis \& Montgomrey, 1995).

Performance is the level of the outputs of the organization after conducting operations on its inputs. It is the output of the activities that occur within the organization (Wit \& Meyer, 1998).

Individual performance has become a topical issue in today's business environment, so much so that organizations go to great lengths to appraise and manage it (Armstrong and Baron, 1998).

Individual job performance is a function of knowledge, skills, abilities, and motivation directed at role prescribed behavior, such as formal job responsibilities (Campbell, 1999).

Job performance is a multidimensional construct consisting of task dimension and contextual dimension (Borman \& Motowidlo, 1993).

Job performance refers to the effectiveness of individual behaviors that contribute to organizational objectives (McCloy et al., 1994; Motowidlo, 2003).

The effective management of individual performance is critical to the execution of strategy and the organization achieving its strategic objectives (Amos, et al., 2004).

A review of literature indicated individual differences such as self-monitoring personality (Caligiuri \& Day, 2000), gender (Sinangil \& Ones, 2003), non-ethnocentrism (Hechanova et al., 2003), Big Five Personality (Mol et al., 2005), communicational ability, relational ability, stress tolerance (Holopainen \& Bjorkman, 2005), cultural flexibility (Shaffer et al., 2006), task and people orientation (Shaffer et al., 2006), goal orientation (Wang \& Takeuchi, 2007) and previous international experience (Varma et al., 2006) related to expatriate job performance.

Hence, after a thorough review of the different concepts of performance, it can be argued that performance in its simplest form is the desired result which the organization seeks to achieve efficiently and effectively.

\section{Research Model}

The proposed comprehensive conceptual model is presented in Figure 1. The diagram below shows that there is one independent variable of JE. There are two dependent variables of OC and JP. It shows the rational links among the variables. The research model is as shown in Figure 1 below.

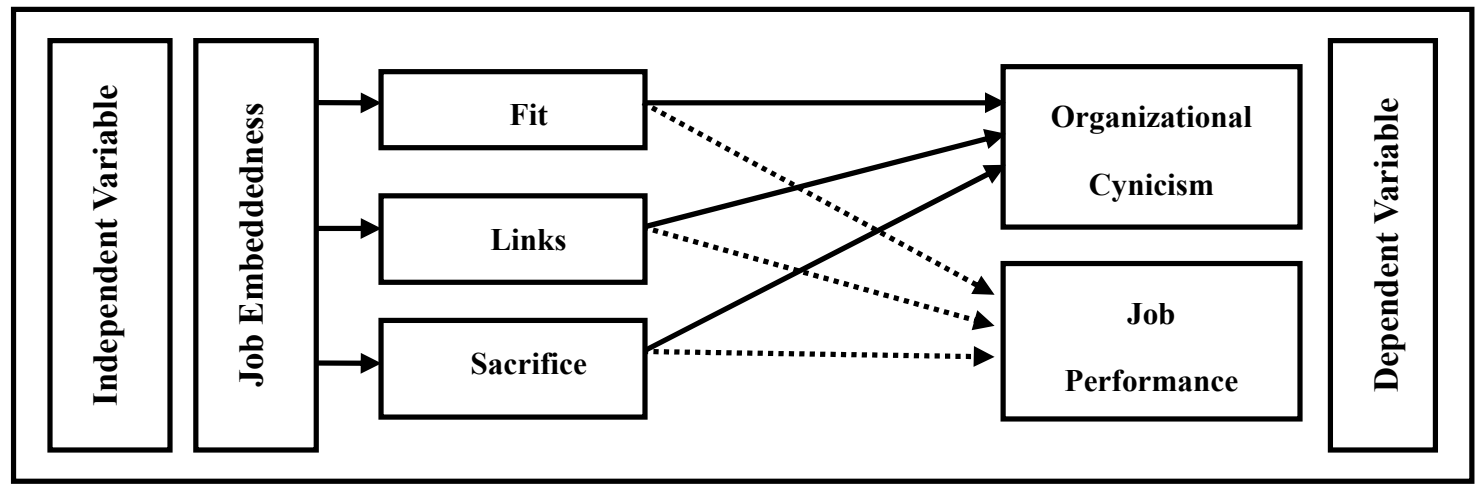

Figure 1. Proposed comprehensive conceptual model

The research framework suggests that JE has an impact on OC and JP. JE as measured consists of fit, links, and sacrifice (Nitchell et al., 2001). 
OC is measured in terms of belief, affect and behavior (Reichers \& Wanous, 1997). JP is measured in terms of task performance, contextual performance, and assignment specific performance (Black \& Porter, 1991; Caligiuri, 1997).

\section{Research Questions and Hypotheses}

The research process includes both questions and hypotheses. The research questions of this study are as follows:

Q1: What is the nature and the extent of the relationship between JE (Fit) and OC at Sadat City University.

Q2: What is the nature of the relationship between JE (Links) and OC at Sadat City University.

Q3: What is the extent of the relationship between JE (Sacrifice) and OC at Sadat City University.

Q4: What is the statistically significant relationship between JE (Fit) and JP at Sadat City University.

Q5: What is the nature and the extent of the relationship between JE (Links) and JP at Sadat City University.

Q6: What is the nature of the relationship between JE (Sacrifice) and JP at Sadat City University.

The following hypotheses were developed to the test if there is a significant correlation between JE, OC and JP.

H1: JE (Fit) of employees has no statistically significant effect OC at Sadat City University.

H2: JE (Links) of employees has no statistically significant impact on OC at Sadat City University.

H3: JE (Sacrifice) of employees has no statistically significant influence on OC at Sadat City University.

H4: JE (Fit) of employees has no statistically significant relationship with JP at Sadat City University.

H5: JE (Links) of employees has no statistically significant effect on JP at Sadat City University.

H6: JE (Sacrifice) of employees has no statistically significant impact on JP at Sadat City University.

\section{Research Methods}

\subsection{Research Population}

The study subjects are employees at University of Sadat City in Egypt. The total population is 692 employees. The research population is illustrated in the following table:

Table 1. Distribution of the population

\begin{tabular}{lcc}
\hline \multicolumn{1}{c}{ Faculty Members } & Number & Percentage \\
\hline Faculty of Veterinary Medicine & 137 & $19.8 \%$ \\
Faculty of Tourism \& Hotels & 89 & $12.9 \%$ \\
Genetic Engineering Research Institute & 117 & $16.9 \%$ \\
Faculty of Physical Education & 174 & $25.1 \%$ \\
College of Education & 33 & $4.8 \%$ \\
Faculty of Commerce & 55 & $7.9 \%$ \\
Faculty of Law & 43 & $6.2 \%$ \\
Institute for Environmental Studies and Research & 44 & $6.4 \%$ \\
\hline Total & 692 & $100 \%$ \\
\hline
\end{tabular}

Source: Staff Members Affairs Department, Sadat City University, Egypt, 2014

Due to the small number of members of the research community at the University of Sadat City, it was decided to study this community using comprehensive inventory (Complete Numeration or Census) in order to get the highest percentage of survey lists. Table 2 illustrates features of sample units. 
Table 2. Characteristics of the sample units

\begin{tabular}{|c|c|c|c|}
\hline \multicolumn{2}{|c|}{ Variables } & Number & Percentage \\
\hline \multirow{3}{*}{ 1-Sex } & Male & 220 & $55 \%$ \\
\hline & Female & 180 & $45 \%$ \\
\hline & Total & 400 & $100 \%$ \\
\hline \multirow{6}{*}{ 2- The Academic Degree } & Professor degree & 70 & $17.5 \%$ \\
\hline & Associate professor & 102 & $25.5 \%$ \\
\hline & Assistant professor & 133 & $33.3 \%$ \\
\hline & Lecturer & 45 & $11.3 \%$ \\
\hline & Demonstrator & 50 & $12.5 \%$ \\
\hline & Total & 400 & $100 \%$ \\
\hline \multirow{3}{*}{ 3- Marital Status } & Married & 313 & $78.3 \%$ \\
\hline & Single & 87 & $21.8 \%$ \\
\hline & Total & 400 & $100 \%$ \\
\hline \multirow{4}{*}{ 4- Age } & Less than 30 years & 61 & $15.3 \%$ \\
\hline & From 30 to 45 & 192 & $48.0 \%$ \\
\hline & More than 45 & 147 & $36.8 \%$ \\
\hline & Total & 400 & $100 \%$ \\
\hline \multirow{4}{*}{ 5- Period of Experience } & Less than 5 years & 203 & $50.8 \%$ \\
\hline & From 5 to 10 & 138 & $34.5 \%$ \\
\hline & More than 10 & 59 & $14.8 \%$ \\
\hline & Total & 400 & $100 \%$ \\
\hline
\end{tabular}

\subsection{Method of Data Collection}

The goal of this study was to examine the relationships between JE, OC and JP at Sadat city University in Egypt. A survey research method was used to collect data in this study. The questionnaire included four questions, relating to JE, OC, OC and biographical information of employees at Sadat city University in Egypt.

A total of 692 questionnaires were sent out in March, 2014 and collected in April 2014. Four hundred and fifteen effective questionnaires were collected (60\% collection rate). Fifteen ineffective ones (with unanswered questions, duplicated entries and inappropriate marks) were excluded, and the number of effective ones was 400 (58\% valid collection rate).

\subsection{Research Variables and Methods of Measuring}

The 18-item scale JE section is based on Nitchell et al., 2001. There were six items measuring fit, six items measuring links, and six items measuring sacrifice.

The 18-item scale OC section is based on Reichers \& Wanous, 1997. There were six items measuring belief, six items measuring affect, and six items measuring behavior.

The 17-item scale JP section is based on Black and Porter, 1991; Caligiuri, 1997. There were five items for task performance, five for contextual performance, and seven for assignment specific performance.

Responses to all items scales were anchored on a five (5) point Likert scale for each statement which ranges from (5) "full agreement," (4) for "agree," (3) for "neutral," (2) for "disagree," and (1) for "full disagreement."

\subsection{Methods of Data Analysis and Testing Hypotheses}

The researcher has employed the following methods: (1) The Alpha Correlation Coefficient (ACC), (2) Multiple Regression Analysis (MRA), and (3) the statistical testing of hypotheses which includes F- test and T-test.

\section{Hypotheses Testing}

Before testing the hypotheses and research questions, descriptive statistics were performed to find out means and standard deviations of JE, OC and JP. 
Table 3. The mean and standard deviations of JE, OC and JP

\begin{tabular}{|c|c|c|c|}
\hline Variables & The Dimension & Mean & $\begin{array}{l}\text { Standard } \\
\text { Deviation }\end{array}$ \\
\hline \multirow{4}{*}{$\mathbf{J E}$} & Fit & 3.4429 & 1.20423 \\
\hline & Links & 3.3771 & 1.08274 \\
\hline & Sacrifice & 3.5758 & 1.03076 \\
\hline & Total Measurement & 3.4653 & 1.08053 \\
\hline \multirow{4}{*}{ OC } & The Belief Dimension & 3.3946 & 1.11660 \\
\hline & The Affective Dimension & 3.2437 & 1.21977 \\
\hline & The Behavioral Dimension & 3.4179 & 1.24235 \\
\hline & Total Measurement & 2.5141 & 0.85691 \\
\hline \multirow{4}{*}{$\mathbf{J P}$} & Task Performance & 3.9150 & 1.17244 \\
\hline & Contextual Performance & 3.7900 & 1.27867 \\
\hline & Assignment Specific Performance & 3.7554 & 1.25281 \\
\hline & Total Measurement & 3.8125 & 1.20832 \\
\hline
\end{tabular}

Table 3 lists the mean and standard deviation among variables. The mean of each variable is more than 3, and this result indicates that the study subjects in general have a higher level of JE, OC and JP. The different facets of JE (fit, links, and sacrifice) are examined. Most respondents identified the presence of sacrifice $(\mathrm{M}=3.57, \mathrm{SD}=1.03)$. This was followed by fit $(\mathrm{M}=3.44, \mathrm{SD}=1.20)$, and links $(\mathrm{M}=3.37, \mathrm{SD}=1.08)$. The different facets of OC (belief, affect and behavior) are examined. Most respondents identified the presence of behavioral dimension $(\mathrm{M}=3.41, \mathrm{SD}=1.24)$. This was followed by belief dimension $(\mathrm{M}=3.39, \mathrm{SD}=1.11)$, and affective dimension $(\mathrm{M}=3.24, \mathrm{SD}=1.21)$. The different facets of JP (task performance, contextual performance, and assignment-specific performance) are examined. Most respondents identified the presence of task performance $(\mathrm{M}=3.91, \mathrm{SD}=1.17)$. This was followed by contextual performance $(\mathrm{M}=3.79, \mathrm{SD}=1.27)$, and assignment specific performance $(\mathrm{M}=3.75, \mathrm{SD}=1.25)$.

6.1 Evaluating Reliability

Table 4. The results of the reliability test for each variable of JE, OC and JP

\begin{tabular}{|c|c|c|c|}
\hline Variables & The Dimension & $\begin{array}{l}\text { Number of } \\
\text { Statement }\end{array}$ & $\mathrm{ACC}$ \\
\hline \multirow{4}{*}{$\mathbf{J E}$} & Fit & 6 & 0.9020 \\
\hline & Links & 6 & 0.8327 \\
\hline & Sacrifice & 6 & 0.8271 \\
\hline & Total Measurement & 18 & 0.9531 \\
\hline \multirow{4}{*}{ OC } & The Belief Dimension & 6 & 0.9379 \\
\hline & The Affective Dimension & 6 & 0.9564 \\
\hline & The Behavioral Dimension & 6 & 0.9365 \\
\hline & Total Measurement & 18 & 0.9765 \\
\hline \multirow{4}{*}{ JP } & Task Performance & 5 & 0.9676 \\
\hline & Contextual Performance & 5 & 0.9488 \\
\hline & Assignment Specific Performance & 7 & 0.9663 \\
\hline & Total Measurement & 17 & 0.9849 \\
\hline
\end{tabular}

ACC was decided to exclude variables that had a correlation coefficient of less than 0.30 when the acceptable limits of ACC range from 0.60 to 0.80 , in accordance with levels of reliability analysis in social sciences (Nunnally \& Bernstein, 1994). To assess the reliability of the data, Cronbach's alpha test was conducted. Table 4 shows the reliability results for JE, OC and JP. All items had alphas above 0.60 and were therefore excellent, according to Langdridge's (2004) criteria. 
The 18 items of JE are reliable due to the fact that the ACC is 0.9531 . The fit, which consists of six items, is reliable since the ACC is 0.9020 while the six items related to links is reliable as the ACC is 0.8327 . Furthermore, the sacrifice, which consists of six items, is reliable due to the fact that the ACC is 0.8271 .

The 18 items of OC are reliable because the ACC is 0.9765 . The six items of belief scales are reliable due to the fact that the ACC is 0.9379 . The affect, which consists of six items, is reliable since the ACC is 0.9564 . The six items related to behavior are reliable as ACC is 0.9365 .

The 17 items of JP are reliable because the ACC is 0.849 . The five items of task performance scales are reliable due to the fact that the ACC is 0.9676 . The contextual performance, which consists of five items, is reliable since the ACC is 0.9488 . The seven items related to assignment-specific performance are reliable as ACC is 0.9663 .

\subsection{The Correlation among the Research Variables}

Table 5. Means, standard deviations and intercorrelations among variables

\begin{tabular}{cccccc}
\hline Variables & Mean & $\begin{array}{c}\text { Std. } \\
\text { Deviation }\end{array}$ & JE & OC & JP \\
\hline $\begin{array}{c}\text { Job } \\
\text { Embeddedness }\end{array}$ & 3.46 & 1.080 & 1.000 & & \\
\hline $\begin{array}{c}\text { Organizational } \\
\text { Cynicism }\end{array}$ & 3.41 & 1.242 & $-0.614^{* *}$ & 1.000 & \\
\hline $\begin{array}{c}\text { Job } \\
\text { Performance }\end{array}$ & 3.81 & 1.208 & $0.499^{* *}$ & $0.473^{* *}-$ & 1.000 \\
\hline
\end{tabular}

Table 5 presents correlation coefficients between the research variables, and the results indicate the presence of significant correlation between variables (JE, OC and JP). JE is average (Mean=3.46; SD.1.080) leading to a higher level of JP for employees (Mean=3.81; SD.1.208). But there are some feelings of cynicism among some employees staff in the organization (Mean=3.41; SD.1.242). Table 5 refers to the existence of a reverse correlation between JE and $\mathrm{OC}(\mathrm{R}=-0.614 ; \mathrm{P}<0.01)$. This shows that the high level of JE helps lower feelings of OC among employees. The table shows the existence of a direct correlation between JE and JP $(\mathrm{R}=0.449 ; \mathrm{P}<0.01)$; the high level of JE leads to the high level of JP. Finally, Table 5 refers to the existence of reverse correlation between OC and JP $(\mathrm{R}=-$ $0.473 ; \mathrm{P}<0.01$ ); rise in the level of OC leads to lower level of JP of employees in the organization.

\subsection{The Relationship between JE (Fit) and OC}

Table 6. MRA results for JE (Fit) and OC

\begin{tabular}{|c|c|c|c|}
\hline The Variables of JE (Fit) & Beta & $\mathrm{R}$ & $\mathrm{R} 2$ \\
\hline $\begin{array}{l}\text { 1. I have a relationship of friendship and love with all the members } \\
\text { of the working group. }\end{array}$ & $0.695^{* *}$ & -0.253 & 0.064 \\
\hline 2. My job enables me to exploit my skills and talents well. & $-0.432^{* *}$ & -0.280 & 0.078 \\
\hline $\begin{array}{l}\text { 3. My values and goals are consistent with the values of the } \\
\text { organization. }\end{array}$ & $-0.161^{*}$ & -0.556 & 0.309 \\
\hline $\begin{array}{l}\text { 4. I can achieve my professional goals through work in this } \\
\text { organization. }\end{array}$ & $-0.390^{* *}$ & -0.577 & 0.332 \\
\hline $\begin{array}{l}\text { 5. I feel satisfied about my progress, during my professional career } \\
\text { in this organization. }\end{array}$ & $-0.686^{* *}$ & -0.622 & 0.386 \\
\hline $\begin{array}{l}\text { 6. If I will stay in this organization, I will achieve more of my } \\
\text { goals. }\end{array}$ & $0.275^{* *}$ & -0.463 & 0.214 \\
\hline - Multiple Correlation Coefficients (MCC) & & 0.747 & \\
\hline - Determination of Coefficient (DF) & & 0.558 & \\
\hline - The Value of Calculated F & & 82.828 & \\
\hline - Degree of Freedom & & 6,393 & \\
\hline - The Value of Indexed F & & 2.80 & \\
\hline - Level of Significance & & 0.01 & \\
\hline
\end{tabular}


According to Table 6, the regression-coefficient between JE (Fit) and $\mathrm{OC}$ is $\mathrm{R}=0.747$ and $\mathrm{R} 2=0.558$. This means that the OC can be explained by the dimensions of JE, for example, "I feel satisfied about my progress, during my professional career in this organization" $(\beta=0.686, \mathrm{R}=0.622$, and $\mathrm{R} 2=0.386)$, "I can achieve my professional goals through work in this organization" $(\beta=0.390, \mathrm{R}=0.577$, and $\mathrm{R} 2=0.332)$, and "my values and goals are consistent with the values of the organization" $(\beta=0.161, \mathrm{R}=0.556$, and $\mathrm{R} 2=0.309)$. Because of the calculated $\mathrm{F}(82.828)$ more than indexed F (2.80) at the statistical significance level of 0.01 , the null hypothesis is rejected.

6.4 The Relationship between JE (Links) and OC

Table 7. The relationship between JE (Links) and OC

\begin{tabular}{|c|c|c|c|}
\hline The Variables of JE (Links) & Beta & $\mathrm{R}$ & $\mathrm{R} 2$ \\
\hline 1. I interact constantly with my colleagues at work. & $-0.307^{* *}$ & -0.573 & 0.328 \\
\hline 2. A lot of co-workers depend on me to help achieving their work. & 0.071 & -0.415 & 0.172 \\
\hline $\begin{array}{l}\text { 3. The current system allows the possibility of forming interacting } \\
\text { work teams }\end{array}$ & $-0.114^{* *}$ & -0.321 & 0.103 \\
\hline $\begin{array}{l}\text { 4. Regular informal meetings are held to strengthen relationships } \\
\text { among workers. }\end{array}$ & $-0.232^{* *}$ & -0.577 & 0.332 \\
\hline 5. I feel that my current job satisfies my need for appreciation. & $-0.746^{* *}$ & -0.622 & 0.386 \\
\hline $\begin{array}{l}\text { 6. The organization allows all members to participate in work } \\
\text { committees. }\end{array}$ & $0.449^{* *}$ & -0.463 & 0.214 \\
\hline - Multiple Correlation Coefficients (MCC) & & 0.757 & \\
\hline - Determination of Coefficient (DF) & & 0.572 & \\
\hline - The Value of Calculated F & & 87.648 & \\
\hline - Degree of Freedom & & 6,393 & \\
\hline - The Value of Indexed F & & 2.80 & \\
\hline - Level of Significance & & 0.01 & \\
\hline
\end{tabular}

According to Table 7, the regression-coefficient between JE (Links) and $\mathrm{OC}$ is $\mathrm{R}=0.757$ and $\mathrm{R} 2=0.572$. This means that the OC can be explained by the dimensions of JE, for example, "I feel that my current job satisfies my need for appreciation" $(\beta=0.746, R=0.622$, and $R 2=0.386)$, "regular informal meetings are held to strengthen relationships among workers" $(\beta=0.232, \mathrm{R}=0.577$, and $\mathrm{R} 2=0.332)$, and "I interact constantly with my colleagues at work" ( $\beta=$ $0.307, \mathrm{R}=0.573$, and $\mathrm{R} 2=0.328$ ).

Thus, the null hypothesis is rejected because JE (Links) and OC have a statistical relationship at the significance level of 0.01 .

\subsection{The Relationship between JE (Sacrifice) and OC}

According to Table 8, the regression-coefficient between JE (Sacrifice) and $\mathrm{OC}$ is $\mathrm{R}=0.775$ and $\mathrm{R} 2=0.483$. This means that the OC can be explained by the dimensions of JE, for example, "I get a good profit meeting level of my performance sufficiently" ( $\beta=0.604, \mathrm{R}=0.583$, and $\mathrm{R} 2=0.339)$, "I have a lot of freedom to choose how to set out my goals" $(\beta=0.257, \mathrm{R}=0.539$, and $\mathrm{R} 2=0.290)$, and "the organization provides a distinct package of health care for workers" ( $\beta=0.103, \mathrm{R}=0.408$, and $\mathrm{R} 2=0.166)$. Therefore, there is enough empirical evidence to reject the null hypothesis. 
Table 8. The relationship between JE (Sacrifice) and OC

\begin{tabular}{|c|c|c|c|}
\hline The Variables of JE (Sacrifice) & Beta & $\mathrm{R}$ & $\mathrm{R} 2$ \\
\hline 1. I have a lot of freedom to choose how to set out my goals. & $-0.257^{* *}$ & -0.539 & 0.290 \\
\hline $\begin{array}{l}\text { 2. I feel that colleagues at work show me a lot of respect and } \\
\text { appreciation. }\end{array}$ & $-0.510^{* *}$ & -0.401 & 0.160 \\
\hline 3. Promotion opportunities in this job are excellent. & $-0.243^{* *}$ & -0.321 & 0.103 \\
\hline $\begin{array}{l}\text { 4. I get a good profit meeting level of my performance } \\
\text { sufficiently. }\end{array}$ & $-0.604^{* *}$ & -0.583 & 0.339 \\
\hline $\begin{array}{l}\text { 5. The organization provides a distinct package of health care for } \\
\text { workers. }\end{array}$ & 0.103 & -0.408 & 0.166 \\
\hline $\begin{array}{l}\text { 6. The organization provides a distinct package of rewards at } \\
\text { retirement. }\end{array}$ & $0.625^{* *}$ & -0.208 & 0.043 \\
\hline - $\quad$ Multiple Correlation Coefficients (MCC) & & 0.775 & \\
\hline - Determination of Coefficient (DF) & & 0.600 & \\
\hline - The Value of Calculated F & & 98.448 & \\
\hline - Degree of Freedom & & 6,393 & \\
\hline - The Value of Indexed F & & 2.80 & \\
\hline - Level of Significance & & 0.01 & \\
\hline$* * \mathrm{P}<.01$ & & & \\
\hline
\end{tabular}

6.6 The Relationship between JE (Fit) and JP

Table 9. MRA results for JE (Fit) and JP

\begin{tabular}{llcc}
\hline \multicolumn{1}{c}{ The Variables of JE (Fit) } & Beta & $\mathrm{R}$ & $\mathrm{R} 2$ \\
\hline 1. I have a relationship of friendship and love with all the members of & 0.136 & 0.394 & 0.155 \\
the working group. & 0.088 & 0.363 & 0.131 \\
2. My job enables me to exploit my skills and talents well. & $0.243^{* *}$ & 0.328 & 0.107 \\
3. My values and goals are consistent with the values of the & & \\
$\quad \begin{array}{l}\text { organization. } \\
\text { 4. can achieve my professional goals through work in this } \\
\quad \text { organization. }\end{array}$ & $0.294^{* *}$ & 0.395 & 0.156 \\
5. I feel satisfied about my progress, during my professional career in & $0.349^{* *}$ & 0.462 & 0.214 \\
$\quad$ this organization. & 0.046 & 0.423 & 0.178 \\
\hline - If I will stay in this organization, I will achieve more of my goals. & & 0.514 & \\
\hline - Multiple Correlation Coefficients (MCC) & 0.264 & \\
- Determination of Coefficient (DF) & 23.521 & \\
- The Value of Calculated F & 6,393 & \\
- Degree of Freedom & & 2.80 & \\
- The Value of Indexed F & & 0.01 & \\
- Level of Significance & & & \\
\hline$* \mathrm{P}<.05$ & & &
\end{tabular}

According to Table 9, the regression-coefficient between JE (Fit) and JP is $\mathrm{R}=0.514$ and $\mathrm{R} 2=0.264$. This means that the JP can be explained by the dimensions of JE, for example, "I feel satisfied about my progress, during my professional career in this organization" $(\beta=0.349, \mathrm{R}=0.462$, and $\mathrm{R} 2=0.214)$, "If I will stay in this organization, I will achieve more of my goals." $(\beta=0.046, \mathrm{R}=0.423$, and $\mathrm{R} 2=0.178)$, and "I can achieve my professional goals through work in this organization" $(\beta=0.294, \mathrm{R}=0.395$, and $\mathrm{R} 2=0.156)$. Because of the calculated $\mathrm{F}(23.521)$ more than indexed F (2.80) at the statistical significance level of 0.01 , the null hypothesis is rejected. 


\subsection{The Relationship between JE (Links) and JP}

Table 10. The relationship between JE (Links) and JP

\begin{tabular}{|c|c|c|c|}
\hline The Variables of JE (Links) & Beta & $\mathrm{R}$ & $\mathrm{R} 2$ \\
\hline 1. I interact constantly with my colleagues at work. & $0.092^{*}$ & 0.288 & 0.082 \\
\hline 2. A lot of co-workers depend on me to help achieving their work. & $0.112^{*}$ & 0.391 & 0.152 \\
\hline $\begin{array}{l}\text { 3. The current system allows the possibility of forming interacting } \\
\text { work teams }\end{array}$ & $0.108^{*}$ & 0.268 & 0.071 \\
\hline $\begin{array}{l}\text { 4. Regular informal meetings are held to strengthen relationships } \\
\text { among workers. }\end{array}$ & 0.082 & 0.395 & 0.156 \\
\hline 5. I feel that my current job satisfies my need for appreciation. & 0.166 & 0.462 & 0.213 \\
\hline $\begin{array}{l}\text { 6. The organization allows all members to participate in work } \\
\text { committees. }\end{array}$ & 0.114 & 0.423 & 0.178 \\
\hline - $\quad$ Multiple Correlation Coefficients (MCC) & \multicolumn{3}{|c|}{0.507} \\
\hline - Determination of Coefficient (DF) & \multicolumn{3}{|c|}{0.257} \\
\hline - The Value of Calculated F & \multicolumn{3}{|c|}{22.612} \\
\hline - Degree of Freedom & \multicolumn{3}{|c|}{6,393} \\
\hline - The Value of Indexed F & \multicolumn{3}{|c|}{2.80} \\
\hline - Level of Significance & \multicolumn{3}{|c|}{0.01} \\
\hline \multicolumn{3}{|c|}{$* \mathrm{P}<.05$} & $\mathrm{P}<.01$ \\
\hline
\end{tabular}

According to Table 10, the regression-coefficient between JE (Links) and JP is $\mathrm{R}=0.507$ and $\mathrm{R} 2=0.257$. This means that the JP can be explained by the dimensions of JE, for example, "I feel that my current job satisfies my need for appreciation" $(\beta=0.166, \mathrm{R}=0.462$, and $\mathrm{R} 2=0.213)$, "the organization allows all members to participate in work committees" $(\beta=0.114, \mathrm{R}=0.423$, and $\mathrm{R} 2=0.178)$, and "regular informal meetings are held to strengthen relationships among workers" $(\beta=0.082, \mathrm{R}=0.395$, and $\mathrm{R} 2=0.156)$. Thus, the null hypothesis is rejected because JE (Links) and JP have a statistical relationship at the significance level of 0.01 .

6.8 The Relationship between JE (Sacrifice) and JP

According to Table 11, the regression-coefficient between JE (Sacrifice) and JP is $\mathrm{R}=0.516$ and $\mathrm{R} 2=0.266$. This means that the JP can be explained by the dimensions of JE, for example, "the organization provides a distinct package of health care for workers" $(\beta=0.555, \mathrm{R}=0.452$, and $\mathrm{R} 2=0.204)$, "I get a good profit meeting level of my performance sufficiently" $(\beta=0.101, \mathrm{R}=0.404$, and $\mathrm{R} 2=0.163)$, and "I feel that colleagues at work show me a lot of respect and appreciation" $(\beta=0.114, \mathrm{R}=0.377$, and $\mathrm{R} 2=0.142)$. Therefore, there is enough empirical evidence to reject the null hypothesis.

Table 11. The relationship between JE (Sacrifice) and JP

\begin{tabular}{|c|c|c|c|}
\hline The Variables of JE (Sacrifice) & Beta & $\mathrm{R}$ & R2 \\
\hline 1. I have a lot of freedom to choose how to set out my goals. & $0.210^{* *}$ & 0.261 & 0.068 \\
\hline $\begin{array}{l}\text { 2. I feel that colleagues at work show me a lot of respect and } \\
\text { appreciation. }\end{array}$ & 0.114 & 0.377 & 0.142 \\
\hline 3. Promotion opportunities in this job are excellent. & $0.109^{*}$ & 0.278 & 0.077 \\
\hline 4. I get a good profit meeting level of my performance sufficiently. & 0.101 & 0.404 & 0.163 \\
\hline $\begin{array}{l}\text { 5. The organization provides a distinct package of health care for } \\
\text { workers. }\end{array}$ & $0.555^{* *}$ & 0.452 & 0.204 \\
\hline $\begin{array}{l}\text { 6. The organization provides a distinct package of rewards at } \\
\text { retirement. }\end{array}$ & $0.217^{*}$ & 0.332 & 0.110 \\
\hline - $\quad$ Multiple Correlation Coefficients (MCC) & & 0.516 & \\
\hline - Determination of Coefficient (DF) & & 0.266 & \\
\hline - The Value of Calculated F & & 23.626 & \\
\hline - Degree of Freedom & & 6,393 & \\
\hline - The Value of Indexed F & & 2.80 & \\
\hline - Level of Significance & & 0.01 & \\
\hline$* * \mathrm{P}<.01$ & & & \\
\hline
\end{tabular}




\section{Research Finding}

The findings support the view that the dimensions of JE (fit, links, and sacrifice) were negatively related with OC (belief, affect, and behavior). The findings reveal that there is a negative relationship between JE and OC.

The results of this research indicate a direct effect relationship and in the opposite direction between the level of JE of employees and OC. Employees with high JE have a higher ability to control their negative emotions towards the organization as compared to their counterparts with low JE. This result is consistent with the findings of Caldwell (2012) regarding the need to adopt a practical strategy for mitigating the effects of OC through following the pattern of transformational leadership which absorbs negative trends of employees. At the same time, it cares about their interests in a manner that achieves the goals of all parties in the organization. This result is also consistent with the findings of the Dinger (2010); Karatepe \& Ngeche, 2012; Reitz et al., 2010; Abad 2010; Watsou, 2011; Chen \& Lim, 2012; Clinton et al., 2012) on the importance of the role played by JE in the development of many of the positive behaviors and reducing negative behaviors in the work environment.

On the other hand, the results support the view that the dimensions of JE were positively related with JP. The results support the view that JE significantly influences JP. The findings reveal that the JE was positively related with JP. Overall findings from this study suggested that JE does affect JP. Management should ensure that JE be applied in the organization through the encouragement of cooperative teamwork. Our findings support the view that more JE are more effective in achieving JP. High JE will be more likely to achieve high JP.

The results support the view that the high JE would lead to more team success, more collective efficacy, better group communication, and more satisfaction of the group members. The results of this research refer to a direct exponential impact relationship between JE and JP of employees. Employees with high JE enjoy higher production capacity compared to their counterparts with low-level JE as the availability of a high level of JE among employees leads to improving the quality of the relationship between employees and their bosses which leads to the improvement of the level of performance.

\section{Recommendations}

1. There is a need to rely on JE to reduce feelings of OC, as JE highly contributes to the reduction of the negative effects of unpleasant events in the work environment. It also plays an important role in the compliance of the individual to stay in the organization and adapt to some of the negative behaviors and the desire to preserve the gains achieved in the future.

2. There is a need to pay attention to JE as an effective strategy to improve relations between employees on the one hand, and their superiors, on the other hand, in order to improve the level of JP within the organization.

3. There is a need to focus on the three dimensions of JE and using them to reduce the feelings of OC of employees in the organization.

- It is found out that an individual's ability to comply with the organization (Fit), and its goals affect the feelings of cynicism toward it. This ability decreased the gap between the values and goals of the individual and the values and goals of the organization and this decreased feelings of $\mathrm{OC}$ among individuals.

- As for the ability to build a network of good organizational relationships (links), the existence of good relations between individuals and the management of the organization contributes to reduce feelings of OC.

- The high volume of moral and material sacrifices that can be borne by the individual as a result of his employment in the organization will affect the level of JE. His view of the adverse events within the organization is also affected, and this reduces the feelings of cynicism about the organization.

4. Promoting and supporting organizational culture encourages JE of employees. This can be achieved through the support and consolidation of mutual trust between the management of the organization, its leadership and its staff, as the high level of JE soften the negative effects of the work environment. This is achieved by increasing the capacity of the individual for compatibility with the organization and the development of relationships with others at all levels of the organization.

\section{Research Implications}

The application of JE has important ramifications for line managers. Leaders in organizations who are worried about losing their most valuable employees should not only study external pay equity or the job satisfaction of their employees, but they should also try to identify viable methods for helping employees become embedded in the organization and the community. 
Managers could establish mentoring programmes to strengthen the links employees have with others in the organization. Managers might encourage work groups to take a prominent role in deciding who to hire into the work group. Organizations can support community outreach programmes to give their employees opportunities to volunteer and become more integrated into their communities.

Employers need to be thoughtful in the recruitment and selection of their employees. They need to provide realistic information to the candidates before employment and subsequently, employers need to assist their employees in planning their careers.

Employers can provide information about community events or amenities. Employers should also consider locating plants or offices near housing sectors that offer affordable dwellings for employees.

The evidence in this research suggests that employers can improve human and social capital in employees by increasing their JE.

Employers can give ample opportunity to build solid organizational links, establish ways for employees to be involved in long-term projects, create opportunity for business and social networking, and provide benefits both financial and psychological that could be seen as sacrifices if one were to leave.

Employers should seek to increase the organizational identification of employees in general, ensuring that those employees who are embedded in their jobs will have a favorable view of their JE, thereby increasing potential outcomes such as internal social capital. Since job embedded employees who disidentify with the organization will have reduced human capital, managers should identify these individuals and seek to remedy issues that are causing disidentification.

\section{Research Limitations}

This research was conducted in light of a set of limitations. First comes the application on the faculty members at the University of Sadat City, including demonstrators, assistant lecturers, lecturers, assistant professors, and professors. Administratives are ruled out to ensure the ability of the sampling unit to fill the questionnaires form. Second: JE is limited to dimensions of on-the-job environment only; not addressing off-the job external environment because of the difficulty of controlling the variables and elements of this environment. Third, this research has been done in the period following the January 25 revolution; OC of employees varied greatly in the form of strikes and demonstrations. Therefore, the dimension of time may be taken into account to study the impact of different findings of this research.

\section{Future Research}

In light of the findings of the research results, a set of proposals to conduct future research are as follows:

1. The impact of psychological capital on supporting the competitiveness of human resources.

2. The impact of JE on job attitudes of employees in the public sector.

3. JE as a mediator variable between the psychological capital and organizational cynicism.

\section{References}

Abraham, R. (2000). Organizational Cynicism: Bases and Consequences. Genetic, Social, and General Psychology Monographs, 126(3), 269-292.

Allen, D. G. (2006). Do organizational socialization tactics influence newcomer embeddedness and turnover? Journal of Management, 32, 237-256. http://dx.doi.org/10.1177/0149206305280103

Amos, T., Ristow, A., \& Ristow, L. (2004). Human Resource Management (2nd ed.). Lansdowne: Juta and Co Ltd.

Andersson, L.M., \&Bateman, T. S. (1997). Cynicism in the workplace: some causes and effects. J. Organiza. Behav. 18, 449-469. http://dx.doi.org/10.1002/(SICI)1099-1379(199709)18:5<449::AID-JOB808>3.0.CO;2-O

Andersson, L. M. (1996). Employee cynicism: An examination using a contract violation framework. Human Relations, 49, 1395-1418. http://dx.doi.org/10.1177/001872679604901102

Arabacı İ. Bakır. (2010). The Effects of Depersonalization and Organizational Cynicism Levels on the Job Satisfaction of Educational Inspectors. African Journal of Business Management, 4(13), 2802-2811.

Armstrong, M., \& Baron, A. (1998). Performance Management - The New Realities. London: IPD.

Borman, W. C., \& Motowidlo, S. J. (1997). Task performance and contextual performance: The meaning for personnel selection research. Human Performance, 10, 99-109. http://dx.doi.org/10.1207/s15327043hup1002_3 
Brandes, P, Dharwadkar, R., \&Dean, J. W. (1999). Does Organizational Cynicism Matter? Employee and Supervisor Perspectives on Work Outcomes. Eastern Academy of Management Proceedings, 150-153.

Brockway, J.H., Carlson, K.A., Jones, S.K., \& Bryant, F.B. (2002). Development and validation of a scale for measuring cynical attitudes toward college. Journal of Educational Psychology, 94, 210-224. http://dx.doi.org/10.1037/0022-0663.94.1.210

Bruch, C., \& Vogel, B. (2006). Emotion as mediators of the relations between perceived supervisor support and psychological hardiness on employee cynicism. J. Organiza. Behav, 27, 463-484. http://dx.doi.org/10.1002/job.381

Caligiuri, P.M., \& Day, D.V. (2000). Effects of Self-Monitoring on Technical, Contextual, and Assignment-Specific $\begin{array}{llll}\text { Performance. Group \& } \quad \text { Organization } & \text { Management, } & \text { 25(2), }\end{array}$ http://dx.doi.org/10.1177/1059601100252004

Campbell, D. T., \& Kenny, D. A. (1999). A primer on regression artifacts. New York: Guilford Press.

Careless, S. A. (2005). Person-job fit versus person-organization fit as predictors of organizational attraction and job acceptance intentions: A longitudinal study. Journal of Occupational and Organizational Psychology, 78, 411-429. http://dx.doi.org/10.1348/096317905X25995

Chatman, J. A. (1989). Improving interactional organizational research: A model of person-organization fit. Academy of Management Review, 14(3), 333-349.

Collis, D.J., \& Montgomrey, C. (1995). Competing on Resources. Harvard Business Review, 73(4), 118-128.

Crossley, C. D., Bennett, R. J., Jex, S. M., \& Burnfield, J. L. (2007). Development of a global measure of job embeddedness and integration into a traditional model of voluntary turnover. Journal of Applied Psychology, 92(2), 1031-1042. http://dx.doi.org/10.1037/0021-9010.92.4.1031

Davenport, N., Schwartz, R.D., \& Eliot, G.P. (2003). Mobbing İ̧s Yerinde Duygusal Taciz (O.C. Önertoy çev.). İstanbul: Sistem Yayınc1lık.

Dean, J. W., Brandes, P., \& Dharwadkar, R. (1998). Organizational cynicism. Academy of Management Review, 23, 341-352.

Dong-Hwan Cho, \& Jung-Min Son. (2011). Job Embeddedness and Turnover Intentions: An Empirical Investigation of Construction IT Industries. International Journal of Advanced Science and Technology, 40, 101-110.

Felps, W., Hekman, D. R., Mitchell, T. R., Lee, T. W., Harman, W. S., \& Holtom, B. C. (2009). Turnover contagion: How coworkers' job embeddedness and coworkers' job search behaviors influence quitting. Academy of Management Journal, 52, 545-561. http://dx.doi.org/10.5465/AMJ.2009.41331075

Fields, D., Dingman, M. E., Roman, P. M., \& Blum, T. C. (2005). Exploring predictors of alternative job changes. $\begin{array}{lllll}\text { Journal of Occupational and Organizational Psychology, } & \text { 78, 63-82. }\end{array}$ http://dx.doi.org/10.1348/096317904X22719

Granovetter, M. (1985). Economic Action and Social Structure: The Problem of Embeddedness. The American Journal of Sociology, 91(3), 481-510. http://dx.doi.org/10.1086/228311

Griffeth, R. W., Hom, P. W., \& Gaertner, S. (2000). A meta-analysis of antecedents and correlates of employee turnover: Update, moderator tests, and research implications for the next millennium. Journal of Management, 26, 463-488. http://dx.doi.org/10.1177/014920630002600305

Gupta, N., \& Jenkins, G. D. (1980). The structure of withdrawal: Relationships among estrangement, tardiness, absenteeism, and turnover. Springfield, VA: National Technical Information Service.

Holopainen, J., \& Bjokman, I. (2005). The personal characteristics of the successful expatriate: A critical review of the literature and an empirical investigation. Personnel Review, 34(1), 37-50. http://dx.doi.org/10.1108/00483480510578476

Holtom, B. C., \& Inderrieden, E. J. (2006). Integrating the unfolding model and job embeddedness model to better understand voluntary turnover. Journal of Managerial Issues, 18, 435-452.

Holtom, B. C., Mitchell, T. R., \& Lee, T. W. (2006). Increasing human and social capital by applying job embeddedness theory. Organizational Dynamics, 35, 316-331. http://dx.doi.org/10.1016/j.orgdyn.2006.08.007 
Holtom, B. C., Mitchell, T. R., Lee, T. W., \& Eberly, M. (2008). Turnover and retention research: A glance at the past, a closer review of the present, and a venture into the future. Academy of Management Annals, 2, 231-274.

Hulin, C. (1998). Behaviors, constructs and time: Potholes on the road well traveled. Invited address, annual meeting of the Society for Industrial and Organizational Psychology, Dallas.

Johnson, L., Jonathan, Anne M., \& O'leary-Kelly. (2003). The Effects Of Psychological Contract Breach and Organizational Cynicism: Not All Social Exchange Violations Are Created Equal. Journal of Organizational Behavior, 24, 627-647. http://dx.doi.org/10.1002/job.207

Kalağan Gamze. (2009). Araştırma Görevlilerinin Örgütsel Destek Algıları İle Örgütsel Sinizm Tutumları Arasındaki İlişki, Yayınlanmamış Yüksek Lisans Tezi, Akdeniz Üniversitesi Sosyal Bilimler Enstitüsü.

Karatepe, O.M., \& Ngeche, R.N. (2011). Does Job Embeddedness Mediate the Effect of Work Engagement on Job Outcomes?: A Study of Hotel Employees in Cameroon. Journal of Hospitality Marketing and Management.

Kutanis, R.Ö., \& Çetinel, E. (2009). Adaletsizlik Algısı Sinizmi Tetikler mi?: Bir Örnek Olay, 17. Ulusal Yönetim ve Organizasyon Kongresi Bildiri Kitab1, Eskişehir, pp. 693-699.

Lee, R.T., \& Ashforth, B.T. (1996). A meta-analytic examination of the correlates of the three dimensions of job burnout. Journal of Applied Psychology, 81(2), 123-133. http://dx.doi.org/10.1037/0021-9010.81.2.123

Lee, T. W., Mitchell, T. R., Sablynski, C. J., Burton, J. P., \& Holtom, B. C. (2004). The effects of job embeddedness on organizational citizenship, job performance, volitional absences, and voluntary turnover. Academy of Management Journal, 47, 711-722. http://dx.doi.org/10.2307/20159613

Lewis, P. (1985). Defining business ethics: like nailing jello to a wall. Journal of Business Ethics, 4, 377-383. http://dx.doi.org/10.1007/BF02388590

Mallol, C. M., Holtom, B. C., \& Lee, T. W. (2007). Job embeddedness in a culturally diverse environment. Journal of Business and Psychology, 22, 35-44. http://dx.doi.org/10.1007/s10869-007-9045-x

McCloy, R. A., Campbell, J. P., \& Cudeck, R. (1994). A confirmatory test of a model of performance determinants. Journal of Applied Psychology, 79, 493-505. http://dx.doi.org/10.1037/0021-9010.79.4.493

Miller, K., \& Bromiley, P. (1990). Strategic Risk and Corporate Performance: An Analysis of Alternative Risk Measure. Academy of Management Journal, 33(4), 756-779. http://dx.doi.org/10.2307/256289

Mitchell, T. R., \& Lee, T. W. (2001). The unfolding model of voluntary turnover and job embeddedness: Foundations for a comprehensive theory of attachment [Electronic version]. Research in Organizational Behavior, 23, 189-246. http://dx.doi.org/10.1016/S0191-3085(01)23006-8

Mol, S.T., Born, M.P., Willemsen, M.E., \& Van Der Molen, H.T. (2005). Predicting Expatriate Job Performance for Selection Purposes: A Quantitative Review. Journal of Cross-Cultural Psychology, 36(5), 590-620. http://dx.doi.org/10.1177/0022022105278544

Motowidlo, S. J. (2003). Job performance. In W. C. Borman, D. R. Ilgen, \& R. J. Klimoski (Eds.), Handbook of psychology: Vol. 12. Industrial and organizational psychology (pp. 39-53). Hoboken, NJ: Wiley.

Nair, P., \& Kamalanabhan, J. (2010). The Impact of Cynicism on Ethical Intentions of Indian Managers: The moderating Role of Seniority. Journal of International Business Ethics, 3(1), 4-29.

Ng, T. W., \& Feldman, D. C. (2009). Occupational embeddedness and job performance. Journal of Organizational Behavior, 30, 863-891. http://dx.doi.org/10.1002/job.580

Ng, T.W.H., \& Feldman, D.C. (2010). The impact of job embeddedness on innovation-related behaviors. Human Resource Management, 49(6), 1067-1087. http://dx.doi.org/10.1002/hrm.20390

O'Brien, A. T., Haslam, S. A., Jetten, J., Humphrey, L., O'Sullivan, L., \& Postmes, T. (2004). Cynicism and disengagement among devalued employee groups: The need to ASPIRe. Career Development International, 9(1), 28-44. http://dx.doi.org/10.1108/13620430410518129

O’Leary, B. S., Lindholm, M. L., Whitford, R. A., \& Freeman, S. E. (2002). Selecting the best and brightest: Leveraging human capital. Human Resource Management, 41, 325-40. http://dx.doi.org/10.1002/hrm.10044

Ozler E. Derya, \& Atalay G. Ceren. (2011). A research to determine the relationship between organizational cynicism and burnout levels of employees in health sector. Business and Management Review, 1(4), 26-38. 
Özler Ergun Derya, Atalay Giderler Ceren, \& Şahin Dil Meltem. (2010). Örgütlerde Sinizm Güvensizlikle Mi Bulaşır? Organizasyon ve Yönetim Bilimleri Dergisi, 2(2), 47-57.

Park, K., \& K. E. Lee. (2004). A Study on the Relationship between Job Embeddedness and Turnover Intention in Korea. Korean Management Review, 33, 5.

Pelit, E., \& Ayduğan, N. (2011). Otel İşletmeleri İşgörenlerinin Örgütsel Sinizm Tutumları Üzerine Bir Araştırma, 12. Ulusal Turizm Kongresi Bildiri Kitab1, Düzce, pp. 286-302.

Pitre, J.L. (2004). Organizational Cynicism at The United States Naval Academy: An Exploratory Study (Master of Arts). Naval Postgraduate School, California.

Reicher, A. E., Wanous, J. P., \& Austin, J. T. (1997). Understanding and managing cynicism about organizational change. Academy of Management Executive, 11(1), 48-59.

Sekiguchi, T., Burton, J. P., \& Sablynski, C. J. (2008). The role of job embeddedness on employee performance: The interactive effects with leader-member exchange and organization-based self-esteem. Personnel Psychology, 61, 761-792. http://dx.doi.org/10.1111/j.1744-6570.2008.00130.x

Shaffer, M.A., Harrison, D.A., Gregersen, H., Black, J.S., \& Ferzandi, L.A. (2006). You can take it with you: Individual differences and expatriate effectiveness. Journal of Applied Psychology, 91, 109-125. http://dx.doi.org/10.1037/0021-9010.91.1.109

Sinangil, H.K., \& Ones, D.S. (2003). Gender differences in expatriate job performance. Applied Psychology: An International Review, 52(3), 461-475. http://dx.doi.org/10.1111/1464-0597.00144

Snow, JL. (2002). Enhancing work climate to improve performance and retain valued employees. J Nurs Adm., 32(7/8), 393-397. http://dx.doi.org/10.1097/00005110-200207000-00007

Taunton, R.L., Boyle, D.K., Woods, C.Q., Hansen, H.E., \& Bott, M.J. (1997). Manager leadership and retention of hospital staff nurses. West J Nurs Res., 19(2), 205-226. http://dx.doi.org/10.1177/019394599701900206

Turner, J.H., \& ve Valentine, S.R. (2001). Cynicism as a fundamental dimension of moral decision-making: a scale development. J. Bus. Ethics, 34, 123-136. http://dx.doi.org/10.1023/A:1012268705059

Urbany, J.E. (2005). Inspiration and cynicism in values statements. $J$. Bus. Ethics, 62, 169-182. http://dx.doi.org/10.1007/s10551-005-0188-2

Uzzi, B. (1996). The sources and consequences of embeddedness for the economic performance of organizations. The network effect. American Sociological Review, 61, 674-698. http://dx.doi.org/10.2307/2096399

Uzzi, B. (1997). Social structure and competition in interfirm networks: The paradox of embeddedness. Administrative Science Quarterly, 42, 33-67.

Valle, M., Leupold, C., \& Leupold, K. (2006). Holding On and Letting Go: The Relationship Between Job Embeddedness and Turnover Among PEM Physicians. Journal of Business Inquiry, 3-10.

Varma, A., Toh, S.M., \& Budhwar, P.S. (2006). A new perspective on the female expatriate experience: The role of host country national categorization. Journal of World Business, 41, 112-120.

Villanova, P., Bernardin, H., Johnson, D., \& Dahmus, S. (1994). The validity of a measure of job compatibility in the prediction of job performance and turnover of motion picture theater personnel. Personnel Psychology, 47, 73-90.

Wang, M., \& Takeuchi, R. (2007). The role of goal orientation during expatriation: A cross-sectional and longitudinal investigation. Journal of Applied Psychology, 93(5), 1437-1445. http://dx.doi.org/10.1037/0021-9010.92.5.1437

Wanous, J. P., Reichers, A. E., \& Austin, J. T. (2000). Cynicism about organizational change: Measurement, antecedents, and correlates. Group and Organization. http://dx.doi.org/10.1177/1059601100252003

Wit, B., \& Meyer, R. (1998). Strategy: Process, Content, Context: An International Perspective. Thompson Business Press.

Yao, X., Lee, T. W., Mitchell, T. R., Burton, J. P., \& Sablynski, C. J. (2004). Job Embeddedness: Current research and future directions. In R. Griffeth \& P. Hom (Eds.), Understanding employee retention and turnover (pp. 153-187). Greenwich, CT: Information Age.

Zapf, D., Knorz, C., \& Kulla, M. (1996). On the Relationship Between Mobbing Faktors and Jop Content, Social Work Environment and Health Outcomes. European Journal of Work and Organizational Psychology, 5(2), 215-237. http://dx.doi.org/10.1080/13594329608414856 